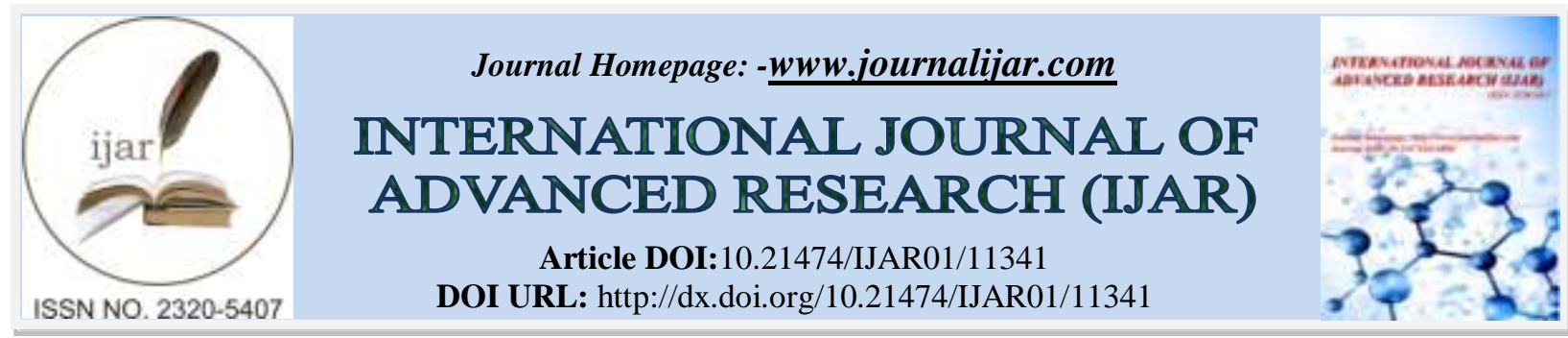

RESEARCH ARTICLE

\title{
COVID 19 AND THE SHADOW PANDEMIC
}

\section{Dr. R. Ramya ${ }^{1}$ and Akshay P. ${ }^{2}$}

1. Assistant Professor \& Head, Research Dept. of Economics, Sri C. Achutha Menon Government College Thrissur 14, Kerala.

2. Assistant Professor (Former Guest Faculty), Research Dept. of Economics, Sri C. Achutha Menon Government College Thrissur 14, Kerala.

\section{Manuscript Info}

Manuscript History

Received: 15 May 2020

Final Accepted: 20 June 2020

Published: July 2020

Key words:-

Shadow Pandemic, Domestic Violence,

Covid 19, Lock Down

\section{Abstract}

Domestic violence against women is a real pandemic that adversely affect all countries across the world. The current Covid 19 pandemic and related lockdown period witnessed a large increase in domestic abuses globally. If such a shadow pandemic is left unaddressed it will ruin the society, and we can't even calculate real social and economic cost associated with it. This paper tries to examine the intensity and change in domestic violence cases before and after the outbreak of Corona virus. A comparative examination of the two time period is also done to find out whether there exists any association between Covid 19 related lock down and domestic violence cases reported.

Copy Right, IJAR, 2020,. All rights reserved.

\section{Introduction:-}

Covid-19 virus has made a dreadful impact upon the entire world and its reverberations upon the global community are far reaching. Along with its threatening smash upon the health of the people, this pandemic has also created a shadow upon the human rights' of the people. When countries resort to lock down as a safeguarding measure to prevent the spread of Covid virus, and when people are sheltering at their home for long, a shadow pandemic start growing. This shadow pandemic is in fact related with the high incidence of domestic violence that women and children have to face. It is quite true that domestic violence was already one of the greatest human rights violations, but its vehemence considerably increased during this critical state of affairs.

The lock down has really put a brake on the mobility of the people and forced them to spend time with in their home. Such a shift in the time use pattern produce a notable impact upon the life of the people. The renowned sociologist Marianne Hester of University of Bristol rightly pointed out that there are much more chance that domestic violence goes up whenever families spend time together. Her views are quite true when we witness a global surge in domestic violence when countries resort to lock down. During this pandemic environment and associated lock down, a great fluctuation in the economic activities along with a massive change in the life style of the people takes place. Such a vast change in the activities and behaviour of the people during the lockdown period has a negative impact upon the family and society. One prime effect of this negative behaviour is the increase in the rate of domestic violence against women and children which is called as 'shadow pandemic' or 'double pandemic'.

Human behaviour is so complicated and it explains the way in which human beings act and interact, which is in turn influenced by the mental, physical and social capacity to respond to internal and external stimuli. A prolonged deviation from a socially engaged life can abrade happiness, both personal and familial. Along with this, intensified 
uncertainty about the future adds up to the mental frustration. These mental frustrations shoot up when people face job insecurity, financial struggles and emotional pressures. According to International labour Organisation (ILO) about 25 million jobs could be lost worldwide due to corona virus pandemic. Such a heavy handed mental pressures often stimulate Sigmund Freud's basic instincts such as sexuality and aggression. His psychodynamic theory itself is founded on the assumption that human behaviour is propelled by thoughts and feelings that lie in our sub conscious mind. The social distancing that we face today produce a significant impact upon our thoughts and feelings, and the frustrations that develop along with will be unleashed on women and children in the form of physical, verbal and emotional violence. Consequently, the rate of domestic violence will propel and it will go out of control. Women and children are also experiencing so many mental stresses just like men in the family, but when physical violence and mental abuse creep up to the maximum they will lose all their hope and happiness to live.

Home is not a safe place for all human beings, it varies accordingly across regions, cultures etc. Sometimes it may turn to be the primary state of abuse. Domestic violence involves a pattern of psychological, physical, sexual, financial and emotional abuse. Acts of assault, threats, humiliation, intimidation etc are also considered acts of domestic violence. We often talked about the economic and social implications of the vicious circle of poverty and women; here too the Covid 19 and related lock down created a vicious circle which put women under a shadow pandemic of domestic violence. Such a shadow pandemic indisputably produces far reaching effects upon the life of women and children. Domestic violence and its repercussions upon the health of women are also massive. It may produce a deleterious effect upon their mental health by putting them into severe depression. From March $25^{\text {th }}$ the Covid-19 related lockdown was imposed in India, a surge in the reported cases of domestic violence appears in the country.

Domestic violence against women is not a new one and it has been there around us for long. As per UN Women in the previous 12 months, 243 million women and girls (aged 15-49) across the world have been subjected to sexual or physical violence by an intimate partner (UN Women, April 6, 2020). The UN Women has pointed out that "As the COVID-19 pandemic continues, this number is likely to grow with multiple impacts on women's wellbeing, their sexual and reproductive health, their mental health, and their ability to participate and lead in the recovery of our societies and economy". The UN agency for Sexual and Reproductive Health (UNFPA) has estimated that there would be 31 million more cases of domestic violence worldwide if lockdowns continue for another six months. The National Family Health Survey (NFHS-4), 2015-16 highlighted that 30 percent of women in India between the age group 15-49 are experiencing physical violence. All the above cited facts and figures clearly depict the seriousness of the issue that we have to tackle with care. According to UN Women if we do not act against shadow pandemic it will add fire to the economic impact of Covid-19. The global cost of violence against women had previously been estimated at approximately USD 1.5 trillion, equivalent to approximately $2 \%$ of the global Gross Domestic Product (UN Women, 2016). This figure will surely increase in the current pandemic situation if we do not consider the problem of domestic violence in a proper manner.

When the deadly virus spreads from one country to the other, our primary focus is on the health and immunity of the people. The lock down and its adverse economic impact is also a serious matter of concern but, unfortunately a major after effect of the lock down which will make a permanent impact upon the present and future generations is often failed to address. That issue is related to the violence that women and children faced within the household. It is quite true that the number and severity of domestic violence cases increased across the World and even women has lost their freedom to come out and report the violence that they face to the concerned authorities. The Domestic Violence Act 2005 elaborates that domestic violence can take on sundry hues - physical, emotional, verbal, sexual, or economic violence. Things get worse when women have limited chances to come out and report the physical and verbal abuses to the authorities or even to peer groups and relatives. A significant number of women faced the same problem and their physical, mental and emotional health is weakened due to such violence.

\section{Evidence of 'Shadow pandemic' in India:}

The recent data on domestic violence revealed that, there is an increase in the rate of reported case of domestic violence across the world. Isabel Yordi, Technical Officer for Gender and Health at WHO, Regional office, Europe pointed out that "We have an increase in reporting from almost all countries". Similarly, WHO's Regional Director for Europe, Hans Henri P. Kluge, pointed out that "countries are reporting up to a $60 \%$ increase in emergency calls by women subjected to violence by their intimate partners in April this year, compared to last". Indian situation is not an exception while comparing to the global scenario. NCW (National commission for Women) has received 123 cases of domestic violence between February 27 and March 22. From the data given below it is quite clear that there 
is a notable increase in the number of complaints related with domestic violence during the corona hit periods including the lock down times. All these revealed the existence of 'shadow pandemic' during the Covid 19 lock down periods.

Reported Cases of Domestic Violence in 2019 and 2020

\begin{tabular}{|c|c|c|}
\hline Month & $\mathbf{2 0 1 9}$ & $\mathbf{2 0 2 0}$ \\
\hline February & 181 & 302 \\
\hline March & 148 & 298 \\
\hline April & 193 & 315 \\
\hline May & 266 & 393 \\
\hline June & 260 & 452 \\
\hline
\end{tabular}

Source: National Commission for women, India, http://164.100.58.238/frmComp_Stat_Overview.aspx

To verify the data statistically we created a null hypothesis:

$\mathrm{H}_{0}$ : There is no association between presence of lockdown and number of domestic violence cases

And an Alternative hypothesis:

$\mathrm{H}_{1}$ : There is association between presence of lockdown and number of domestic violence cases

And to verify the hypothesis an independent $t$ test is used. The test results are given below.

\begin{tabular}{|l|l|l|l|l|l|l|}
\hline Year & N & Mean & SD & t & df & Sig \\
\hline 2019 & 5 & 209.6000 & 51.50049 & -3.735 & 8 & .006 \\
\hline 2020 & 5 & 352.0000 & 67.94483 & & & \\
\hline
\end{tabular}

From the above table it is quite clear that the domestic violence data for the year 2019 has a mean of 209.6 with $\mathrm{SD}=51.50049$, where in 2020 it is 352.00 and 67.94483 respectively. To test the hypothesis that whether there is any association between the lockdown and number of domestic violence cases reported an independent sample t-test is performed. The data set satisfied the normality assumption which is necessary for conducting t-test. Additionally the assumption of homogeneity of variance has tested and satisfied via Levene's $F$ test, $F=.925, p=.364$. The independent sample t-test was associated with a statistically significant effect, $\mathrm{t}=-3.735, \mathrm{p}=0.006$. So we can reject the null hypothesis $\left(\mathrm{H}_{0}\right)$. A positive trend between the increased period of lock down as well as increasing rate of domestic violence cases reported can be seen.

Not only a shadow pandemic in association with domestic violence cases but also Covid 19 and corresponding lock down period has its 'shadow effects' on children too. Children who witness such domestic abuse may try to frame a mind set of their own thinking that violence is a reasonable way to resolve conflicts within and outside the family. It may also generate an attitude that there is nothing wrong in degrading the value of women which will produce negative impacts upon their attitude towards gender roles when they grown up. Deputy Director of Child line India Foundation, Harleen Walia has stated that, the number of calls to the child help line number increased by $50 \%$ after the commencement of national lockdown from March 25. The patriarchal nature of family now too controls the lives of a large number of women which even restricts them come out and report the violence they face. These unwritten rules in the society frequently restrict women to reach out for external help and raising complaints and it is stronger in the rural areas as well as among marginalised communities. The domestic abuse thus creates far reaching reverberations upon the life of women and children and it will also impact the society and its attitude towards gender roles. Domestic abuses also adversely affect the mental health of women and children which leads to a serious deterioration of the capabilities of a large section of human capital.

\section{Dealing with the problem of Domestic Violence: Can Nudges help?}

The domestic violence or domestic abuse in fact start with the basic instinct of dominance came into the mind of one partner and it may be also due to strong emotions, or any ego problems, or due to extreme anger, or may even due to some complexes. A prompt and apt solution for the problem of domestic violence is an urgent matter of concern but it is not an easy task. Traditional law and order system along with penalties and other punishments can't be 
considered as the one and only weapon to control this shadow pandemic. Those who resort to domestic abuses had a mindset which is often ignited by so many psychological factors. Results showed that violence against women by their husbands in a marital definition is associated with demographic factors like age, socio-economic and sociocultural factors like poverty and types of marriage, behavioral factors like aggressive behavior etc (Jean Jacques Kisaka Ngimbi, et.al, 2019). The violence is based on a set of behaviors that cause physical, psychological, moral and social suffering or even sex with the woman (Bailard, TJ, 1998). All these reference citations clearly revealed that domestic violence or abuse is not a single dimensional problem which can be solved so easily. It has a wide range of implications which have to be dealt with much care and caution.

In this scenario, one prominent suggestion is associated with a series of nudges that can influence aptly on the people's behaviour. Self-awareness should be imparted through intrusive nudges. Active advertisement regarding the need to protect women and children from violence should be provided. Government should broadcast creative advertisements with catchy slogans which will have a psychological impact upon the public. A more easy access to the women and child protection authorities should be ensured and the information about women helps line and online complaint systems has to be channelized through the grass root level. Providing information about the nature of complaints raised may also act as a good nudge. Since local self government plays a predominant role in imparting such awareness to every nook and corner of the society. The easiness of online complaint registration will also be communicated in a comprehensive manner.

It is also very important to create an attitudinal change among the public which will produce a psychological impact which will surely strengthen the belief that women have equal rights with men and they should be treated equally. A self psychological empowerment of women is also a key element which will put a strong block on domestic violence. Because if women are psychologically strong and empowered, and if any sort of violence they face within or outside the household, they will react boldly. They will not remain silent and if they are abused they will move outside and report the complaints to the concerned authorities. If women strongly resists against the violence, in due course it will came to the bare minimum, and it will spread a wave of no violence against women within and outside. It is already a fact that herd behaviour can produce lot of changes in the society. Herd Behaviour is about making a decision on the basis of behaviour/choices of others. Such herd behaviour is functioning among those women who are afraid of reporting if they are abused. If they found that other women who face violence came forefront and report the same to the authorities, and such an action can break the status - quo of women in the matter of domestic violence. Nudges can also help men to control their aggressive behaviour. If the authorities help to occupy men in different activities which in turn help them to mitigate their aggressive behaviour and thus tries to reduce violence to a certain extent. Online games, talent show platform through community websites etc. can be choose as some nudges for this. Awards on community basis for husbands those who actively participate in the child care, family responsibilities might give a desirable result

\section{Conclusion:-}

The incidence of domestic violence has become a serious issue during the current scenario. The violence against women and children is shooting up and if left unattended in a proper manner it will lead to a real shadow pandemic in this crisis situation. . Many of the domestic violence cases have a psychological factor behind it. A detailed look at the lock down throws light on the uncertainty regarding jobs and associated mental struggles is the real fire that ignites a long stretch of complex feelings inside the mind of human beings which in turn resulted in abuses upon women and children. So how to tackle such psychological disorders is a matter of great concern because if left unanswered it will adversely affect the overall welfare of the community. Also the depression faced by victims of domestic violence should be addressed in a proper manner. Government along with other NGOs has to formulate prudent nudges to boost up the willpower of women to break the cultural barriers that stop them from filing complaints. Active involvement and empowerment of women is essential in the process of curtailing this double pandemic. Governments have to come up with strong nudges and ideas to curb the rate of domestic violence and proper ideas should be formulated from grass root level for addressing this issue.

\section{Reference:-}

1. "Almost 25 million jobs could be lost worldwide as a result of COVID-19”, ILO, March 18, 2020.

2. Bailard, TJ Saltzman LE, Gazmararian JA, Spitz AM, Lazorick S, et al. (1998 ) Violence during pregnancy: Measurement issues. American Journal of Public Health 88(2): 274-276. 
3. "Coronavirus: I'm in lockdown with my abuser" https://www.bbc.com/news/world-52063755, accessed 3rd April 2020.

4. “COVID-19, Domestic Abuse and Violence: Where Do Indian Women Stand?”, EPW, April 17, 2020.

5. "Domestic Violence Spikes During Coronavirus As Families Trapped At Home" https://10daily.com.au/news/australia/a200326zyjkh/domestic-violence-spikes-during-coronavirus-as-familiestrapped-at-home-20200327, accessed 2nd April 2020.

6. Jean Jacques Kisaka Ngimbi, Joel Kafumbi Katsiatsia' Gertrude Lundu Yenamawu and Joseph Mayituka Newa' (2019)"'Psychosocial Factors Associated with Domestic Violence Inflicted on Women by their Husbands at Kenge, Kwango Province, DRC, Biomedical Journal of Scientific and Technical Research, Vol 18, Issue 2, pp 13451-13459

7. "Lockdowns around the world bring rise in domestic violence" https://www.theguardian. com/society/2020/mar/28/lockdowns-world-rise-domestic-violence, accessed 3rd April 2020.

8. National Bureau of Economic Research ,https://www.nber.org.

9. National commission on women, http://164.100.58.238/frmComp_Stat_Overview.aspx.

10. National Family Health Survey (NFHS-4), 2015-2016.

11. "Responding to the shadow pandemic: Initiatives to address violence against women and girls during COVID19", June 6, 2020.

12. "Shadow pandemic: how covid19 crisis exacerbating gender inequality", United nation foundation, April 14, 2020.

13. "The shadow pandemic of gender-based violence", Atlantic council, May 1, 2020.

14. Toby D. Goldsmith, MD (2020) What causes domestic violence?https://psychcentral.com/lib/what-causesdomestic-violence/

15. "Violence against women and girls: the shadow pandemic", UN Women, April 6, 2020. 